\title{
THE NEW CEFTA WITH SPECIAL REFERENCE TO ITS INFLUENCE ON ACCESSION TO THE EUROPEAN UNION AND ON THE REPUBLIC OF CROATIA
}

\begin{abstract}
Marta Krizmanić ${ }^{*}$
Summary: In 1992 Poland, Czechoslovakia and Hungary signed the Central European Free Trade Agreement (CEFTA). In time, Czechoslovakia split into the Czech Republic and Slovakia, while Slovenia, Romania, Bulgaria, Croatia and Macedonia joined CEFTA. However, Poland, the Czech Republic, Hungary, Slovenia and Slovakia left CEFTA on entering the European Union, which Bulgaria and Romania also joined later. The latter two, however, signed, along with 8 other parties (Albania, Bosnia and Herzegovina, FYR Macedonia, Moldova, Croatia, Serbia, Montenegro and UNMIK Kosovo), the Agreement on Amendment of and Accession to the Central European Free Trade Agreement (CEFTA 2006) on 19 December 2006. This new CEFTA will replace over thirty bilateral free trade agreements concluded among them. After a short introduction, this paper argues that the purpose of CEFTA is to enable its members to enter the EU more easily, and thus serves as an instrument of EU accession. Reference is made to the most important benefit of the old CEFTA, which was the common preparation for integration to the EU's market. By analysing the impact of the old CEFTA as a pre-accession instrument, an analogy is made with the new CEFTA, where emphasis is placed on its role as a regional cooperation instrument.

The paper aims to compare the provisions of CEFTA 2006, the Treaty establishing the European Community, and the Stabilisation and Association Agreement, mainly from the perspective of Croatia. Particular provisions of the Consolidated Version of CEFTA 2006 are discussed separately in the fourth part of this paper.
\end{abstract}

\section{Introduction}

Discussion of trade liberalisation in South Eastern Europe (SEE) should perhaps start with the Memorandum of Understanding on Trade Facilitation and Liberalisation, concluded on 27 June 2001 within the framework of the Stability Pact for SEE. The Memorandum was signed by the representatives of Albania, Bosnia and Herzegovina, Bulgaria, FYR

\footnotetext{
* Marta Krizmanić, LLB, company lawyer and postgraduate degree candidate at the Faculty of Law, University of Zagreb.
} 
Macedonia, Croatia, Romania, while Yugoslavia and Moldova joined later. The main obligation arising from the Memorandum was for the countries to start negotiations on bilateral free trade agreements which should be concluded before the end of 2002. The outcome was the signing of more than 30 bilateral free trade agreements.

Under the 'patronage' of the European Union (EU) and the Stability Pact, '[a]fter seven months of intensive negotiations', ${ }^{1}$ Albania, Bosnia and Herzegovina, Bulgaria, FYR Macedonia, Moldova, Croatia, Romania, Serbia, Montenegro and the United Nations Interim Administration Mission in Kosovo (UNMIK) on behalf of Kosovo signed in Bucharest on 19 December 2006 the Agreement on Amendment of and Accession to the Central European Free Trade Agreement (CEFTA 2006) ${ }^{2}$ (hereinafter 'Agreement', 'CEFTA 2006', 'the new CEFTA'). The anticipated date of ratification of the Agreement was at the latest 1 May 2007 under the condition that the signatories (except Bulgaria and Romania) ratify the Agreement at the latest on 31 March 2007. Even before the expiry of that deadline, it was clear that the Agreement would not enter into force as predicted. In the period in between, while the Agreement was not yet in force, the parties would continue to apply the bilateral free trade agreements. The Agreement would enter into force on the $30^{\text {th }}$ day following the day that the fifth signatory deposited the documents of ratification. The remaining parties would apply bilateral free trade agreements until each of them had ratified the Agreement.

The bilateral free trade agreements had already brought free trade to the signatories, although not completely liberalised, but the new CEFTA would not provide that either. The new CEFTA 'liberalises more than 90 percent of trade and almost all trade in industrial products'. ${ }^{3}$ The bilateral free trade agreements had established a free trade area for almost all industrial products and some agricultural products.

The complex network of a large number of agreements, 'the spaghetti bowl', ${ }^{4}$ was consolidated into one Agreement. However a question arises - why is one multilateral agreement a better choice? One agreement cre-

1 A Milovan 'Upitno zaživljavanje nove CEFTE do svibnja' Privredni vjesnik (Zagreb 19 March 2007) <http://www.privredni-vjesnik.hr/index.cgi?A=I\&SIF=00003\&BR=003455\& DA=20070319> accessed 11 July 2007 (author's translation from Croatian to English).

2 Agreement on Amendment of and Accession to the Central European Free Trade Agreement (CEFTA 2006) available at <http://www.stabilitypact.org/wt2/TradeCEFTA2006. asp> accessed 29 June 2007.

3 _ 'U Bukureštu potpisan sporazum CEFTA-e', 19 December 2006, <http://www.mingo. $\mathrm{hr} /$ default.asp?id=1265\&glink $>$ accessed 29 June 2007 (author's translation from Croatian to English).

4 L Niseteo Stipić, 'Proširenje Cefte' Privredni vjesnik, (Zagreb 13 November 2006) <http:// www.privredni-vjesnik.hr/index.cgi?A $=\mathrm{I} \& \mathrm{SIF}=00002 \& \mathrm{BR}=003439 \& \mathrm{DA}=20061113>\quad$ ac cessed 12 July 2007. 
ates a better perception of the region as a whole, it is uniform, and the procedures are simplified and therefore easier to apply. The new CEFTA means a deeper reinforcement of economic relationships, simplified custom procedures, more efficient and quicker exchange at borders, and a unification of procedures. The new CEFTA would help countries join the EU more quickly, more easily, and make them better prepared. In fact, this is the most important role of the two CEFTAs, the old ${ }^{5}$ one, as the facts demonstrate, and the new one, as it is planned.

When discussing the potential increase in mutual trade among the new CEFTA members, two different views should be heard. Some suppose that CEFTA 2006 will necessarily increase mutual trade. On the other hand, some believe that there will be no significant increase.

First, the idea will be heard that the new CEFTA could produce a great number of positive effects. Namely, by establishing a free trade area, a new market arises 'consisting of the sum of the markets that join'. ${ }^{6}$ The expansion of the markets would resolve, or at least start to resolve, some of the numerous problems of the SEE countries. Prices would fall following increased competition on the home market, in the region, and also in third countries. Furthermore, the employment rate would rise. The CEFTA area in turn would become more attractive for foreign direct investment. Clearly, the trading power of each country would be stronger within the area than it would be outside. Finally, state policies would be more stable and security would be stronger, which, taken together, would allow for the strengthening of European trading networks. ${ }^{7}$

However, some opine that there is no reason to expect a significant increase in trade within the area through the new CEFTA. The first reason is that "trade is already liberalised and, for the time being, the existing bilateral agreements are not applied entirely. A multilateral agreement will not by itself encourage trade; it is necessary to develop other instruments as well, firstly through joint projects. ${ }^{8}$ Furthermore, a period of

\footnotetext{
5 The term 'old CEFTA' implies CEFTA before the signing of the Agreement on Amendment of and Accession to the Central European Free Trade Agreement in 2006 (CEFTA 2006), often excluding Croatia in that respect. The chronology of CEFTA is given in the second part of this paper.

6 G Cassano and S Onelli, 'Vantaggi e prospettive di un'area di integrazione commerciale nell' Europa di Sud Est' <http://www.mincomes.it/balcani/vantaggi_prospettive/indice. htm> accessed 29 June 2007 (author's translation from Italian to English.

7 Compare G Cassano and S Onelli, 'Vantaggi e prospettive di un'area di integrazione commerciale nell'europa di Sud Est' <http://www.mincomes.it/balcani/vantaggi_prospettive/ indice.htm> accessed 29 June 2007.

8 K Jurlin and V Samardžija, 'Područje slobodne trgovine jugoistočne Europe već je formirano' (Comment 13 February 2006) <http://www.entereurope.hr/cpage.aspx?page=clanci. aspx\&pageID=171\&grupaID=2\&clanakID=801 $>$ accessed 29 June 2007 (author's translation from Croatian to English).
} 
time, perhaps a few years, needs to pass before the Agreement can work. The second reason is that the $\mathrm{EU}$ is the main trading partner of each of the countries in the region, and that ' $[\mathrm{t}] \mathrm{he}$ experience of CEFTA tells us that the free trade area has not significantly increased mutual trade, because the signatories were primarily encouraged to strengthen cooperation with the EU'. ${ }^{9}$ Regarding foreign investments, it seems that they have increased in the old CEFTA countries because of "the certainty of EU accession' 10 not because those countries were members of that regional trade organisation.

CEFTA's economic role is very important, but so is the political one. Here, the objective is to join the EU. The instrument of free trade is at the same time an objective and a means to that end. In this light, Croatia entered into the SAA with the European Communities and their Member States, ${ }^{11}$ as has Macedonia. In order to comply with CEFTA's purpose of integration into the EU, it is necessary for all CEFTA members to conclude free trade agreements with the EU.

Pekka Huhtaniemi, Under-Secretary of State, during the ceremony of the signing of the new CEFTA and on behalf of the Finnish EU Presidency, made the following claim for CEFTA 2006: 'This inclusive Regional Free Trade Agreement is a substantial step forwards both economically and politically'. ${ }^{12}$ He went on to recall the European Council's Conclusions when it welcomed the signing of the Agreement: 'The new CEFTA will be a substantial step forward both economically and politically's and that the European Council 'looks forward to a regional and inclusive trade agreement'. ${ }^{14}$

This paper will attempt to highlight CEFTA as an instrument for accession to the EU. If we consider it as an instrument for a regional approach and for a regional policy, we can see CEFTA as a mechanism for regional cooperation, a condition set in the SAA and in the Stabilisation and Association Process.

\footnotetext{
9 Ibid.

10 Ibid.

11 Published in Croatia, Official Gazette, International Agreements 14/2001. The acronym SAA will be used in this Paper for the particular 'Croatian' Stabilisation and Association Agreement. The SAA was signed on 29 October 2001 and entered into force on 1 February 2005.

12 P Huhtaniemi at the signing ceremony of the modernised CEFTA (Statement 19 December 2006) <http://213.214.146.178/public/default.aspx?contentid=851 13\&nodeid=1 5145\&contentlan=2\&culture=en-US $>$ accessed 29 June 2007.

13 Brussels European Council, Presidency Conclusions (14/15 December 2006) Point 14 <http://www.consilium.europa.eu/ueDocs/cms_Data/docs/pressData/en/ec/92202. pdf $>$ accessed 12 July 2007.

14 Ibid.
} 
Not contrary to the notion of CEFTA as an instrument of the SAA, economic cooperation in the region strengthened by CEFTA is at the same time the foundation, the instrument and the purpose of CEFTA. Why foundation? It is because trade is the main basis of CEFTA. Its mechanism is trade between its members. Why instrument? Because only through economic cooperation and trade does CEFTA exist. And finally, why purpose? For the reason that the sound application of CEFTA will lead to good economic cooperation and result in the countries, if not the region as whole, becoming part of the EU. This economic cooperation is very significant 'as trade and investment are important tools in moving the region as a whole forward. ${ }^{15}$ Besides, 'the new CEFTA, along with the SAA process, provides a spur to further reducing national obstacles to trade and investment and opening up markets to competition and growth. ${ }^{16}$

Concerning the SEE countries' obligations towards the EU and the World Trade Organisation (WTO), CEFTA is 'fully compatible with their WTO and EU obligations'. ${ }^{17}$ Besides being a preparation for entrance to the EU, CEFTA 2006 is also preparation to enter the WTO.

\section{Remarks on CEFTA in connection to accession to the EU}

CEFTA was founded in 1992 in Krakow when the founders, Poland, Czechoslovakia and Hungary, signed the Central European Free Trade Agreement. CEFTA's main objectives were to establish a free trade area, promote investments, and integrate economies.

In parallel with CEFTA, the founders liberalised their trading relations with the EU. Trading integration is very important with regard to relations with the EU, since it represents the 'indicators of economical integration'. ${ }^{18}$

CEFTA has expanded several times. At first, the number of members expanded (without an expansion of territory) when Czechoslovakia split into two states in 1993. Slovenia joined CEFTA in 1996, Romania in 1997, Bulgaria in 1998, Croatia in 2003 and Macedonia in 2006. Members of CEFTA had set conditions for joining. One was being a member

15 Zagreb Declaration of the 10th Meeting of the Heads of State and Government of the South-East European Co-operation Process (SEECP) Europe's New South East (Zagreb 11 May 2007) Point 13, <http://www.mvpei.hr/seecp/docs/070514_SEECP\%20Summit\%20 Declaration\%20usvojeno\%20110507.pdf > accessed 27 June 2007.

16 Ibid.

17 Conclusions of the Regional Table of the Stability Pact (Zagreb 10 May 2007) 3 <http:// www.stabilitypact.org/pages/press/detail.asp?y=2007\&p=543> accessed 29June 2007.

18 V Šošić and B Vujčić, 'Trgovinska integracija i pridruživanje Hrvatske Europskoj uniji' in K Ott (ed) 'Pridruživanje Hrvatske Europskoj uniji: ususret izazovima pregovora., treći svezak' (2005) Institut za javne financije 60. 
of WTO, and another was being an associated member of the EU. Nowadays, these conditions no longer apply. As for WTO relations, it is necessary for a potential CEFTA member to comply with WTO rules, while some sort of institutional relation between the potential CEFTA candidate and the EU should also exist.

On joining the EU on 1 May 2004, Poland, the Czech Republic, Hungary, Slovenia and Slovakia left CEFTA, which was downsized just as the EU was enlarged. 1 May 2004 is a significant date, not only for the EU and its big enlargement, but also for other multilateral and bilateral economical arrangements in Europe. The European Economic Area (EEA), the world's most integrated regional market, expanded, the Baltic Free Trade Area (BAFTA) ceased to exist, and a large number of bilateral agreements that the new EU members had concluded with countries that were not members of the EU and EEA were to be terminated.

For a time, CEFTA consisted only of Croatia, Bulgaria and Romania. The future of CEFTA was therefore in doubt, especially taking into account that Bulgaria and Romania were very close to entering the EU and Croatia was not very far from that goal.

After Macedonia had joined CEFTA in the middle of 2006, the new CEFTA idea finally came to life when the Agreement was signed at the end of 2006. CEFTA would once more be large. The predicted 'big bang'19 enlargement and expansion of CEFTA had finally occurred.

However, Romania and Bulgaria became members of the EU on 1 January 2007 and left CEFTA.

Old CEFTA played a very important role in EU accession but it should not be forgotten that CEFTA was no more than an interim arrangement to serve a basic market integration function as part of EU pre-accession. ${ }^{20}$ When the old CEFTA and BAFTA members (Estonia, Lithuania and Latvia) left those organisations and entered the EU, we can say that CEFTA and BAFTA had acted 'as subregional components of EU pre-accession, [and] enlargement proper meant that they had reached the point where their purpose was served'. ${ }^{21}$

The question arises whether new CEFTA will be able to follow old CEFTA's role in offering a step towards the EU. To put the question another way, we can ask whether it will 'reproduce its central European role or redefine itself in South East Europe. ${ }^{22}$

\footnotetext{
19 M Dangerfield, 'Subregional Integration and EU Enlargement: Where Next for CEFTA? (2006) Journal of Common Market Studies 44 (2) 315.

20 Ibid 309.

21 Ibid 307.

22 Ibid 308.
} 
The EU market, the world's biggest market, consists of approximately 469 million consumers. The market of the future CEFTA composed of 'Croatia, Bosnia and Herzegovina, Montenegro, Serbia, Macedonia, Albania, Kosovo (UNMIK) and Moldova, will represent a market of around 27 million potential consumers. ${ }^{23}$ These figures motivate the countries to join both organisations, and at the same time help them to visualise the benefits of accession.

The EU is the most important trade partner of the SEE countries just as was the case for the Central and Eastern European countries before they joined the EU.

Broadly speaking, trade is the essence of European integration, and a single market is 'one of the main accomplishments of economic integration within the EU. ${ }^{24}$ A very efficient method of achieving good trade exchange is by establishing free trade areas. The EU applies the instrument of establishing free trade areas in its enlargement policy, and in its Neighbourhood Policy as well. Free trade areas with third countries form a very important part of the European Neighbourhood Policy.

The requirement of an established market economy and the ability to cope with competitive pressure and market forces within the EU, along with their subcriteria, ${ }^{25}$ are a part of the economic criteria set as EU accession criteria. The ability to cope with competitive pressure and market forces within the EU 'implies the minimal level of competitiveness in the main economical sectors of the candidate country. ${ }^{26}$ Among other things, 'the level and the speed of trade integration with EU before enlargement (the extent and the types of categories of goods in exchange with Member States) ${ }^{27}$ is to be evaluated in that respect.

CEFTA 2006 is one of the methods to help achieve the objective of coping with the competitiveness and strength of the EU market.

The EU market is constantly changing and the acquis communautaire and the field of adaptation and harmonisation are expanding (ie with every enlargement of the EU and with the passing of time). Therefore, candidate countries have to put in further efforts during the accession process. It has to be borne in mind that competitiveness is evaluated in accordance with the changed market. Through the enlargement of the

\footnotetext{
23 Milovan (n 1).

24 A-M Boromisa 'Što proširenje Europske unije znači za Hrvatsku' in: K. Ott, ed. Pridruživanje Hrvatske Europskoj uniji: ususret izazovima pregovora treći svezak (2005) Institut za javne financije 34 (author's translation from Croatian to English).

25 See V Šošić and B Vujčić, 'Trgovinska integracija i pridruživanje Hrvatske Europskoj uniji' in K Ott (ed), 'Pridruživanje Hrvatske Europskoj uniji: ususret izazovima pregovora., treći svezak' (2005) Institut za javne financije.

26 Boromisa (n 24) 31.

27 Boromisa (n 24) 31.
} 
EU, the internal market is also being enlarged, competition grows, and consequently the demands to cope with competitive pressure and market forces alter as well. Candidate countries constantly have to track all of these changes and adjust to them. In other words, and to borrow an apt saying, the EU is a 'moving target'.

\section{CEFTA as an EU policy towards the SEE countries}

The EU aspires to ensure peace, freedom, stability, economic growth and development in the SEE countries. These countries have the opportunity to conclude stabilisation and association agreements. Indeed, the EU believes that trading policy is key for stabilisation in the region and for economic development.

Olli Rehn, European Commissioner for Enlargement, stated that 'Regional cooperation is a key element of EU policy in the region. It will help bring the region closer to the EU. ${ }^{28}$ Referring to CEFTA, and with a view to other agreements (the Energy Community Treaty and the European Common Aviation Area Agreement), he stated that 'Recent agreements and initiatives testify that the agendas of regional cooperation and European integration are increasingly intertwined. ${ }^{29}$

The EU develops its trade relations in the region on three levels. The first one is the bilateral level and includes the signing of Stabilisation and Association Agreements. The multilateral one is in respect of supporting the countries of the region to become members of the WTO. The third one is a regional one, supporting and encouraging CEFTA.

SAAs regulate liberalisation of trade in goods with the aim of developing a free trade area that is gradual and asymmetric in respect of full liberalisation of imports into the EU, and gradual in respect of imports into the Stabilisation and Association countries. Regional cooperation is a very important factor of evaluation for the countries of the region in their approach to the EU, and free trade areas are one method of forming best regional cooperation. In the Preamble of the SAA, it is laid down that, among other things, the importance given to the SAA within the framework of the Stabilisation and Association Process of the SEE countries and within the framework of the Stability Pact is to be taken into consideration. The commitment of the parties to free trade, in accordance with the rights and obligations arising from the WTO, is especially taken into account. One of the scopes of the SAA is the creating of a new climate for economic relations in the region, especially for the development of trade

28 O Rehn, 'Regional Cooperation at the heart of EU' (Speech) (SEECP Summit Zagreb 11 May 2007) <http://europa.eu/rapid/pressReleasesAction.do?reference=SPEECH/07/ 302\&format=HTML\&aged=0\&language=EN\&guiLanguage $=e n>$ accessed 27June 2007 .

29 Ibid. 
and investment. The SAA in Croatia's case provides that one of the aims of the Association is to develop gradually a free trade area between the Community and Croatia, as well as to foster regional cooperation in all the fields covered by the SAA (Art 1, SAA).

In Art 12, the SAA provides for Croatia's obligation towards regional cooperation in all the fields covered by the SAA with any country or countries that have already signed a Stabilisation and Association Agreement. After signing the SAA, Croatia is obliged to start negotiations and to conclude bilateral conventions on regional cooperation. The aim of the negotiations and the convention is to enhance the scope of cooperation between the Stabilisation and Association countries and, most importantly, to establish a free trade area in accordance with the parties and according to WTO rules. The Macedonian SAA contains the very same provision. Both Croatia and Macedonia were obliged to conclude the conventions within two years of the entry into force of the SAA.

This new approach of the EU, the regional approach, "made closer contractual ties with the target countries' ${ }^{30}$ In contrast, the former association agreements, called the European Agreements, neither had these provisions nor did they include the obligation stemming from the Stabilisation and Association Process. The EU perceives 'free trade solely as an initial step in a long-term process'. ${ }^{31}$

Croatia has further accepted, in Art 13 of the SAA, the obligation to cooperate with other countries concerned with the Stabilisation and Association Process in accordance with the principles and objectives of the SAA.

Finally, the possibility for cooperation with other EU candidate countries is foreseen in Art 14 of the SAA.

The SAA is 'the main pre-accession instrument'. ${ }^{32}$ Although not mentioned in the SAA, its goal is 'EU membership'. ${ }^{33}$ In that respect, we can define CEFTA as the sub-pre-accession instrument with the aim of entering the EU.

CEFTA is an instrument to meet the obligation for SAA regional cooperation. The candidate countries and future candidate countries fulfil a large part of their SAA obligations through CEFTA. As elaborated in Part 4 of this paper, CEFTA's obligations intertwine with EU obligations. In some parts, CEFTA even implies the application of European law.

30 D Bechev, 'Carrots, sticks and norms: the EU and regional cooperation in Southeast Europe' (2006) Journal of Southern Europe and the Balkans, 8 (1) 32.

31 Ibid 38.

32 S Rodin, 'Sporazum o stabilizaciji i pridruživanju - interpretacija i primjena' (Presentation) slide 5 <http://eu.pravo.hr/fileadmin/Europsko/dokumenti/Powerpoint/SSP_01_ 2004_Rodin.ppt> accessed 29 June 2007 (author's translation from Croatian to English).

33 Ibid. 


\section{Consolidated version of CEFTA 2006}

The Agreement on Amendment of and Accession to the Central European Free Trade Agreement (CEFTA 2006) consists of two annexes. The first one is the Consolidated Version of the Central European Free Trade Agreement (CEFTA 2006) ${ }^{34}$ and the second one consists of a list of bilateral free trade agreements that will terminate when CEFTA 2006 comes into force.

In this part of the paper, a comparison among the Agreement, the SAA and the Treaty establishing the European Community (TEC) ${ }^{35}$ will be made with the goal of better understanding the objective of the Agreement's provisions and making correlations among their respective provisions.

The Consolidated Version of CEFTA 2006 starts with the preamble and continues with the first article that sets the objective of establishing a free trade area transitional period, ending at the latest by 31 December 2010, in accordance with the WTO provisions.

The Agreement further consists of 7 chapters that will be discussed in consecutive order in this paper.

The beginning of Chapter 1 regulating the general obligations applicable to trade in all goods provides that the goods in the trade between the parties shall be classified in accordance with the Combined Nomenclature (CN) (Art 2 para 1) in the same manner as it is classified in the EU. The SAA regulates the classification of goods with the same method (Art 15 para 2 SAA).

\footnotetext{
34 The first annex consists of the Preamble, 52 Articles, 4 Joint Declarations and the following 9 Annexes:

Annex 1 Product lines falling within CN chapters 25 to 97 considered agricultural products in the Agreement

Annex 2 Industrial products not liberalised on the date of entry into force of the Agreement (referred to in Art 8 paras 1 and 2)

Annex 3 Agricultural concessions (referred to in Art 10 para 1)

Annex 4 Protocol concerning the definition of the concept of 'originating products' and methods of administrative cooperation (referred to in Art 14 paras 1 and 3)

Annex 5 On mutual administrative assistance in customs matters (referred to in Art 14 paras 2 and 3)

Annex 6 Existing bilateral investment agreements between parties (referred to in Art 30 paras 1,2 and 3 )

Annex 7 Agreements and Conventions relating to the protection of intellectual property rights (referred to in Art 39 para 2 and Art 38 paras 2 and 3)

Annex 8 Appointment of a mediator (referred to in Art 42 para 3)

Annex 9 Constitution and functioning of the arbitral tribunal (referred to in Art 43 para 3).

35 Treaty establishing the European Community (consolidated text), OJ C 325/1, 24 December 2002.
} 
The basic duty to which the successive reductions set out in the Agreement are to be applied shall be the duty that was actually applied in trade between the parties on the day preceding the entry into force of the Agreement (Art 2 para 2).

The parties are obliged to abolish all customs duties on exports, charges having equivalent effect, and export duties of a fiscal nature in trade between them starting on the date of entry into force of the Agreement (Art 4 para 1) and it is prohibited to introduce new ones (Art 4 para 2). As for customs duties on imports, a standstill clause is introduced. In trade between the parties, starting from the day preceding the signature of the Agreement, it is prohibited to introduce new customs duties on imports, charges having equivalent effect, and import duties of a fiscal nature, and those which already exist shall not be increased (Art 5). The parties are obliged, starting from the entry into force of the Agreement, to abolish customs fees contrary to Art VIII of GATT, as well as any other similar charges between them in their trade (Art 6).

The SAA anticipates that upon its entry into force, customs duties on imports into the Community of products originating in Croatia shall be abolished (Art 17 para 1 SAA) and customs duties on imports of products originating in the Community into Croatia shall be abolished gradually within the transitional period laid down in the SAA (Art 18 paras 1, 2 and 3 SAA), although Croatia agreed to reduce its customs duties in trade with the Community more rapidly if its general economic situation and the situation of the economic sector concerned permit (Art 21 SAA). The charges with an effect equivalent to customs duties on imports are abolished upon the entry into force of the SAA (Art 19 SAA).

Art 25 of the TEC provides that custom duties on imports and exports, as well as charges having equivalent effect and custom duties of a fiscal nature, are prohibited between member states.

It is very interesting to have a parallel view of one of the so-called 'mirror provisions' of the SAA and TEC and, in respect of this Paper, of the Agreement. Mirror provisions are those SAA provisions 'that are identical or substantially similar to the provisions of the TEC ${ }^{36}$ and they 'require knowledge of EC law' ${ }^{37}$ But are they really the same provisions? Do we interpret them in the same way? And what about the Agreement's provisions? Are they substantially similar to those of the TEC and SAA? The answer is no. We will explain why once we have compared the mentioned provisions.

On the day of the Agreement's entering into force, all quantitative restrictions on imports and exports, as well as measures having equivalent

36 S Rodin (n 32) slide 10.

37 Ibid slide 23. 
effect, will be abolished in trade between the parties (Art 3 para 1) and the introduction of new ones is prohibited (Art 3 para 2).

The SAA regulates the abolition of quantitative restrictions and measures having equivalent effect on imports into the Community for goods originating in Croatia (Art 17 para $2 \mathrm{SAA}$ ) and the abolition of the quantitative restrictions and measures having equivalent effect on imports into Croatia for products originating in the Community (Art 18 para 4 SAA) upon the entry into force of the SAA. Upon the entry into force of the SAA, the parties shall abolish between themselves all quantitative restrictions on exports and measures having equivalent effect (Art 20 para 2 SAA).

The TEC provides that all quantitative restrictions on imports and exports and all measures having equivalent effect between the members states shall be abolished (Arts 28 and 29 TEC). The TEC provides in Art 30 that the provisions of Art 28 and 29 do not preclude prohibitions or restrictions on imports, exports or goods in transit justified on grounds of public morality, public policy or public security; the protection of health and life of humans, animals or plants; the protection of national treasures possessing artistic, historic or archaeological value; or the protection of industrial and commercial property. It is also provided that such prohibitions or restrictions shall not constitute a means of arbitrary discrimination or a disguised restriction on trade between Member States.

The SAA in Art 42 regulates authorised restrictions with the approach that it does not preclude prohibitions or restrictions on imports, exports or goods in transit justified on grounds of public morality, public policy or public security; the protection of health and life of humans, animals or plants; the protection of national treasures of artistic, historic or archaeological value or the protection of intellectual, industrial and commercial property, or rules relating to gold and silver. However, such prohibitions or restrictions cannot be applied if they constitute a means of arbitrary discrimination or a disguised restriction on trade between Croatia and the Community.

The Agreement allows the general exemption in Art 17 in a very similar way. It does not preclude the prohibition or restriction on imports, exports, or goods in transit justified on grounds of public morality, public policy or public security, the protection of health and life of humans, animal or plants, the protection of national treasures possessing artistic, historic or archaeological value, the protection of intellectual property or rules relating to gold or silver or the conservation of exhaustible natural resources, if such measures are made effective in conjunction with restrictions on domestic production or consumption. Again, such prohibitions or restrictions cannot be applied if they constitute a means of arbitrary discrimination or a disguised restriction on trade between the parties. 
The European Court of Justice has an abundance of case law on the free movement of goods. At this point it is interesting to note that the European Court of Justice interprets differently the provisions of the TEC and similar provisions in association agreements.

A very important case in this respect is Polydor ${ }^{38}$ concerning the relations between intellectual property rights and the free movement of goods. This case is significant since it shows that similar provisions in an association agreement and in the TEC can serve different purposes. The issue relates to similar terminology stemming from different sources (different agreements) that are not interpreted equally. Namely, it was emphasised in the judgment summary that the Agreement between the European Economic Community and the Portuguese Republic of 1972 (Portuguese Agreement) did not have the same purpose as the TEC, even though it consisted of unconditional restraint of some trade restrictions between the Community and Portugal (just like the quantitative restrictions and measures having equivalent effect) provided for in the TEC. The similarity of terms is not sufficient reason for transposing the case law of the European Court of Justice to the provisions of the Portuguese Agreement (as expressed in point 15 of the Judgement). The reason is that the purposes of the Portuguese Agreement and TEC are different. The purpose of the Portuguese Agreement is to consolidate and to extend the economic relations existing between the Community and Portugal, and to ensure the development of their trade relations (point 10 of the Judgement). The objective of the TEC, on the other hand, is to unite national markets as closely as possible in a single market with all the characteristics of a national market (point 16 of the Judgement). Finally, it is concluded that the Polydor restrictions are justified on the ground of the protection of industrial and commercial property, although such justification would not be possible within the Community (point 19 of the Judgement).

This case is very important for the purpose of this paper since it shows different interpretations of equal provisions in different circumstances. It therefore follows that while interpreting CEFTA provisions, the object and purpose have to be taken into account. This could especially be emphasised in competition law where, as explained later in the paper, the Agreement explicitly determines the application of the rules and principles of European competition law.

Returning to the Agreement, apart from the general exemption, it also foresees a security exemption. A party has the possibility to take any necessary measure to prevent the disclosure of information contrary to its essential security interests as laid out in Art 18.

38 Case 270/80 Polydor Ltd. and RSO Records Inc. v. Harlequin Records Shops Limited and Simons Records Limited [1982] ECR 329. 
As the Agreement determines in Chapter 2, Industrial Products are products originating in parties falling within CN Chapters 25 to 97, except those listed in Annex 1 (Art 7). The parties are obliged to abolish all customs duties on imports, as well as all charges having equivalent effect and all import duties of a fiscal nature in trade between them on the date of entry into force of the Agreement on all products except those subject to bilateral concessions (Art 8 para 1). The exemptions are listed in Annex 2 . These products will be liberalised in the transitional period ending on 31 December 2008. In old CEFTA the trade of industrial products was fully liberalised. ${ }^{39}$ In new CEFTA, a small amount of protected products is introduced.

Chapter 3 of the Agreement relates to Agricultural Products. The Agreement determines that agricultural products are those originating in the parties falling within CN Chapter 1 to 24 and those products listed in Annex 1 (Art 9). All Customs duties on imports, all charges having equivalent effect, other import duties of a fiscal nature on products listed in Annex 3 shall be reduced or abolished in accordance with the schedules laid out in Annex 3 (Art 10 para 1). The parties are obliged to apply Most Favoured Nation duty on the imports of products listed in Annex 3 in the cases where they would be lower than the preferential customs duties laid out in Annex 3 (Art 10 para 2).

The lists of products are the same as those in the bilateral agreements. Therefore, CEFTA 2006 does not introduce any new liberalisation of trade of agricultural products, but the parties are obliged to examine within the Joint Committee, not later than 1 May 2009, the possibilities of granting each other further concessions (Art 10 para 3). The agricultural policy of the parties is not limited in any way by the Agreement, but the parties are obliged to inform the Joint Committee of changes in their agricultural policies or applied measures which may affect the conditions of agricultural trade among the parties. They are also obliged to refrain from using export subsidies and to abolish any such existing subsidies in their mutual trade, regardless of Art 21 para $2^{40}$ (Art 11). The rights and obligations of parties concerning the application of sanitary and phytosanitary measures are to be applied in accordance with the WTO Agreement on the Application of Sanitary and Phytosanitary Measures.

The rights and obligations of the parties concerning Technical Barriers to Trade and the elimination of those barriers will be determined

\footnotetext{
39 Compare A Milovan, 'Upitno zaživljavanje nove CEFTE do svibnja' Privredni vjesnik (Zagreb 19 March 2007) <http://www.privredni-vjesnik.hr/index.cgi?A=I\&SIF=00003\&BR=00 $3455 \& D A=20070319>$ accessed 11 July 2007 (author's translation from Croatian to English).

40 Art 21 para 2 provides that Art 21 para 1 which regulates state aid will not apply to agricultural products regulated in Chapter 3.
} 
in accordance with the WTO provisions except for the exemptions prescribed in Chapter 4, Art 13 of the Agreement. In Art 13 para 4 it is prescribed that the parties are obliged to enter into negotiations to conclude multilateral agreements on harmonisation of their technical regulations and standards, and on the recognition of the conformity assessment procedures between themselves, all in accordance with the WTO Agreement on Technical Barriers to Trade and other international agreements, all before 31 December 2010.

General Provisions deal with the Operating rules, Competition Rules and Contingent Protection Rules.

The rules of origin and the methods for administrative cooperation in customs matters are laid out in Annex 4 (Art 14) and are very similar to those provided in the bilateral agreements. The novelty is the possibility of application of diagonal cumulation of origins of goods in mutual trade with the possibility of later cumulation as well with the EU once all the states comply with the provisions and conditions of the cumulation.

The Agreement prohibits fiscal discrimination. The parties are not allowed to introduce any measure or practice of an internal fiscal nature establishing, directly or indirectly, discrimination between the products originating in the parties. If there is any such measure in force, the parties are obliged to abolish it. Secondly, the products which are exported to the territory of one of the countries are not allowed to benefit from repayment of domestic taxation that exceeds the amount of indirect taxation imposed on them (Art 15). SAA regulates the fiscal discrimination prohibition in a similar way in Art 34.

As for payments, payments in freely convertible currencies in connection with trade in goods between the parties are free and without barriers. Transfers of those payments to the territory of the party where the creditor resides are also free and without any restrictions (Art 16).

The competition rules consist of regulations concerning state monopolies, competition rules in a narrow sense and state aid (Arts 19-21). All the provisions concerning competition law rules are comparable to the analogical provisions of the TEC and SAA. At this point, mirror provisions are encountered again.

The parties are obliged to adjust state monopolies of a commercial character or state-trading enterprises in order to ensure that there is no discrimination between enterprises of the parties relating to the conditions under which products are marketed, all in accordance with WTO rules. No new discrimination may be introduced. The parties are obliged to inform the Joint Committee about the measures they will apply in order to comply with the provisions of the Agreement concerning the abovementioned rules (Art 19). There is a very similar provision on state monopolies, albeit with some distinctions, in the texts of the SAA and TEC. 
All agreements between undertakings, decisions by associations of undertakings and concerted practices between undertakings which have as their object or effect the prevention, restriction or distortion of competition in the territories of the parties as a whole or in a substantial part of them are incompatible with the proper functioning of the Agreement insofar as they may affect trade between the parties (Art 20 para 1 point a).

The abuse of a dominant position by one or more undertakings in the territories of the parties as a whole or in a substantial part thereof is incompatible with the proper functioning of the Agreement insofar as it may affect trade between the parties (Art 20 para 1 point b). These competition law rules are the mirror provisions of Art 70 para 1 point i) and ii) of the SAA. The Agreement determines that the above-mentioned competition law rules provided for in Art 20 para 1 and 2 shall be applied at the latest by 1 May 2010 to the activities of all undertakings, including public undertakings and undertakings to which the parties grant special or exclusive rights.

As for undertakings entrusted with the operation of services of general economic interest or having the character of a revenue-producing monopoly, Art 20 para 1 and 2 applies insofar as it does not obstruct the performance of that particular task in law or fact (Art 20 para 3). The provisions of Art 20 para 1 point a) shall not be applied on the agricultural products listed in Annex 3 if they form an integral part of a domestic market organisation.

Just as the Agreement refers to the obligation of complying with the principles of the European competition law rules applicable in the European Community, especially provided in Arts 81, 82 and 86 of the TEC, the same rule can be found in the SAA in Art 70 para 2. Therefore, European law has to be consulted while applying the Agreement and interpreting it.

Besides the obligation to apply European law, the parties are expressly obliged by the Agreement to apply the national competition law rules in a manner which eliminates the above-mentioned procedures which are contrary to competition law rules. They are also obliged to cooperate and exchange information in this field.

The measures to be taken in the case of a breach of the provisions set out in Art 20 paras 1 to 4 are those prescribed in Art 24 which regulates the conditions and the procedure of performing the measures referred to in Arts 20, 21 and 23.

Regarding state aids, every aid granted by a party or through state resources in any form which distorts or threatens to distort competition by favouring certain goods is held to be incompatible with the proper functioning of the Agreement, insofar as it may affect trade between the 
party concerned and other parties (Art 21 para 1). This article does not relate to agricultural products (Art 21 para 2).

The Agreement mentions once more the obligation to apply the European law principles and rules. It refers to the state aid provisions set out in Art 87 of TEC (Art 21 para 4). The SAA again mentions the same obligation of the parties in Art 70 para 2. We come to the obligation relating to the implementation of the same provisions in national legal systems (Art 21 para 3). With the scope of ensuring transparency in the area of state aid, the parties are obliged to report to the Joint Committee annually and, upon request, to other parties on the total amount and distribution of the aid given (Art 21 para 7).

However, the parties still have the right to take countervailing measures in compliance with the relevant articles of GATT and the WTO Agreement on Subsidies and Countervailing Measures or internal legislation (Art 21 para 6).

In the Joint Declaration referring to Arts 20 and 21, the parties declare that they will bring the competition provisions into compliance with the principles of Arts $81,82,86$ and 87 of the TEC and that they will establish an operationally independent authority responsible for the application of competition and state aid rules, all of which not later than 1 May 2010.

In comparative terms, this field of law is very rich in detail and practice, especially European competition law, but also the national competition laws of the member states. The provisions of the Agreement on competition law contribute to this field of law in the region and mark a considerable step forward.

Contingent Protection Rules relate to Anti-Dumping Measures, General Safeguards, Conditions and Procedures for Taking Measures, and Balance of Payments Difficulties.

Dumping is prohibited by the Agreement (as it is in Art 37 para 1 SAA) within the meaning of Art VI of GATT. In the case of breach, the parties have the right to take appropriate measures in accordance with the WTO Agreement on Implementation of Art VI of GATT and the conditions laid down in the Joint Declaration referring to Arts 21, 22 and 23. The parties are obliged to inform the Joint Committee and the concerned party accordingly (Art 22). In the Joint Declaration, the parties ensure that they shall not apply anti-dumping, countervailing or safeguard measures until they have developed internal procedures for them and until they have determined technical issues relating to the application of those measures.

Independently of WTO rules and the above-mentioned Joint Declaration, the Agreement foresees General Safeguards. In accordance with the 
General Safeguards provisions, the importing party may apply bilateral safeguard measures to another exporting party in accordance with the procedure set out in Art 24 in the event that any product is imported in such increased quantities and under such conditions from a party to the Agreement so as to cause or threaten to cause any serious injury to domestic producers of like or directly competitive products in the territory of the importing party or any serious disturbances in any sector of the economy which could bring serious deterioration in the economic situation of the importing party (Art 23).

The Agreement also foresees a special protection mechanism for agricultural products. This is provided on account of the sensitivity of the agricultural products market. In the case where imports of products originating in one party, which are the subject of concessions granted in Annex 3, cause serious disturbance to the markets or to the domestic regulatory mechanisms in another party, the parties are obliged to enter into consultations immediately and find a solution. Even before resolving the problem, the concerned party may take the appropriate measures it deems necessary (Art 23 bis).

If in any of the parties a serious balance of payments difficulty or any imminent threat of it arises, the party concerned may adopt restrictive import measures in accordance with the WTO rules. The duration of such measures is limited and the intensity is not to go beyond what is necessary to remedy the balance of payments situation (Art 25).

If a party determines that dumping is taking place in trade with another party within the meaning of Art VI of GATT, appropriate measures can be taken in accordance with the WTO Agreement on the Implementation of Art VI of GATT and in accordance with the Joint Declaration relating to this article. It is necessary to inform the concerned party and the Joint Committee (Art 22).

New trade issues cover the fields of trade in services, investments, public procurement and protection of intellectual property, all in accordance with international standards. In each of these fields, the evolutionary clause is provided in order to accelerate the procedures, but also to allow for the possibility to determine better conditions.

The Agreement defines trade in services in accordance with Art I and XXVIII of the General Agreement on Trade in Services - GATS (Art 26). The parties are obliged to broaden their cooperation for the purpose of liberalisation and the mutual opening of their services markets in respect of European integration, and in the frames of GATS (Art 27). The Agreement provides for the evolutionary clause with the objective of fostering trade in services which will be at the centre of future liberalisation in SEE. In accordance with the clause, the Joint Committee will annually review this cooperation and, if appropriate, will recommend launching 
negotiations for further liberalisation in accordance with Art V of GATS (Art 29). It is agreed to promote the development of electronic commerce between the parties, in particular in connection with cooperating on market access (Art 28).

Regarding investment, the parties are obliged to establish and maintain a stable, favourable and transparent position, legal protection and security in their territory and to regulate their legislation in that respect. They are also obliged to exchange information within the Joint Committee (Arts 32 and 33). A remark needs to be made that the countries have already concluded bilateral investment agreements which are still in force and which are enumerated in Annex 6 (Art 30). The evolutionary clause was formed within the scope of broadening investments and in respect of coordinating policies and investments, reviewing investment legislation, exchanging information within the Joint Committee, and reviewing the possibility of approving similar supplementary advantages to investors of one of the other parties, or to investors of third countries (Art 33).

Public procurement, within the meaning of this Agreement, is procurement conducted by central or sub-central government entities or other relevant entities. The definitions of Art I of the WTO Agreement on Government Procurement apply (Art 34). All the provisions of the Agreement relating to services (Arts 26 to 29) are not to be understood as imposing an obligation for public procurement procedures. The parties are obliged to conduct public procurement procedures in the spirit of open and effective competition, in a transparent and reasonable manner, and all suppliers have to be treated equally. Measures relating to duties or other measures relating to imports are not included within the public procurement provisions of the Agreement. It is necessary to ensure that all the parties receive equally favourable treatment at the latest by 1 May 2010 (Art 35). The public procurement provisions anticipate the evolutionary clause with the goal of accelerating the process of opening government procurement markets towards other parties. If a party grants advantages to a third county, it shall also arrange for opportunities for other parties to the Agreement to enter negotiations so that these advantages may be extended to them on a reciprocal basis (Art 36).

In the field of intellectual property rights, the parties are obliged to enable efficient protection in accordance with international standards, especially in accordance with TRIPS, and to continue to apply the agreements listed in Annex 7. The parties who are not parties to those agreements are obliged to join them and implement the obligations arising from those agreements not later than 1 May 2014 (Art 38). Again, the evolutionary clause lays down that if a party agrees to more favourable conditions with a third party, it shall arrange for consultations with the other parties with a view to extending these advantages to them on a reciprocal basis. 
Functioning rules relate to the composition, competence and procedures of the Joint Committee; the fulfilment of obligations of the parties; consultations; arbitration; the obligation of the parties to promptly publish legislation relating to the issues covered in the Agreement; the obligation of the parties to respond to all requests made by another party; the possibility of a party to maintain or establish a customs union, free trade area or to arrange for frontier trade to the extent that it does not affect negatively the trade regime of the Agreement; the duration of the Agreement for an indefinite period of time; the procedure of denunciation; and the depositary of the Agreement (the Republic of Croatia).

Since the parties may wish to make further effort for better and closer relations and cooperation and to make further and quicker liberalisation of a higher level, the Agreement contains evolutionary clauses in several places. The general evolutionary clause is placed at the end of the Agreement. It enables the party which considers that it would be in the interest of the economies of the other parties to develop and deepen relations arising out of the Agreement, to present such a proposal to other parties. This proposal can be further presented to the Joint Committee which will analyse it and make a proposal to open respective negotiations (Art 45).

Comparing the new CEFTA with the old CEFTA, the novelty of the former is the formation of a permanent secretariat located in Brussels to support the Joint Committee which consists of the representatives of all parties and which supervises and implements the Agreement.

Four Joint Declarations are positioned at the very end of the Agreement. The first one relates to the obligation of applying several WTO rules irrespective of whether a party is at the same time a member of WTO. The second Joint Declaration relates to the cooperation between the parties and their mutual Assistance. The last two Declarations relate respectively to Arts 20 and 21 on one hand, and to Arts 21, 22 and 23 on the other.

\section{Conclusion}

Many people define the importance of CEFTA as a kind of training to enter the EU, 'the preparation and waiting room for EU membership', ${ }^{41}$ 'the waiting room or preparatory step', ${ }^{42}$ or 'the lobby of the EU'. ${ }^{43}$

41 B Ranogajec ‘Članstvo u CEFTA-i - čekaonica za EU' Interview with O Spevec, Privredni vjesnik (Zagreb 28 October 2002) <http://www.privredni-vjesnik.hr/index.cgi?A=I\&SIF $=00001 \& B R=003273 \& D A=20021028>$ accessed 29 June 2007 (author's translation from Croatian to English.

42 O Spevec, 'Republika Hrvatska - članica CEFTA-e' (2003) Računovodstvo, revizija i financije, 3, 17 (author's translation from Croatian to English).

43 'U CEFTA-u ulazi Makedonija, otvorena vrata jugoistoku Europe' (29 November 2005) <http://www.mingorp.hr/default.asp?id=923\&glink=> accessed 29 June 2007 (author's translation from Croatian to English. 
The biggest and most frequently mentioned benefit of the old CEFTA was the common preparation it provided for integration into the EU market. Consequently, the conclusion can be drawn that CEFTA 2006 is a good instrument, offering a secure route towards EU membership and providing preparation for the internal market of the EU. Only secondarily is it a good step for the economies and trade relations of the parties. In the past two waves of accession, CEFTA was the instrument of the new EU members that facilitated integration into the EU through common preparation and through the process of harmonising legislation with that of the EU.

The new CEFTA will also not only offer sound preparation but will also be a good instrument for accession to the EU. The Stabilisation and Association Process and the regional approach provisions constitute part of the stabilisation and association agreements. They also make a difference between the Stabilisation and Association Agreements and the European Agreements. Therefore, CEFTA plays an extra role, acting an instrument of regional cooperation.

To what extent the new CEFTA can help Croatia enter the EU will only be seen following the achievement of this most important goal of Croatia's foreign policy. Without doubt, the aspects covered in this paper suggest that the new CEFTA will play a significant part in Croatia's accession to the EU. 